\title{
1 Construction History and Timber Use of the Medieval Settlement Nadymskiy Gorodok in \\ 2 the Northwestern Siberian Forest-Tundra
}

3

4 Gulzar T.Omurova ${ }^{\mathbf{b}^{*}}$, Andrea Seim ${ }^{\mathrm{c}}$,Valentin V.Barinov ${ }^{\mathrm{d}}$, Oleg V. Kardash ${ }^{\mathrm{e}}$, Vladimir

5 S. Myglan ${ }^{d}$

6

$7 \quad{ }^{a}$ Kyrgyz National Agrarian University, Mederov Str., 68, 720005, Bishkek, Kyrgyz Republic

$8 \quad$ b Central Asian Institute for Applied Geosciences, T. Frunze Str., 73/2, 720027, Bishkek, Kyrgyz

9 Republic

$10{ }^{\mathbf{c}}$ Chair of Forest Growth, Institute of Forest Sciences, Albert-Ludwig-University of Freiburg,

11 Tennenbacherstr., 4, 79106 Freiburg, Germany

12 d Siberian Federal University, Siberian Dendrochronological Laboratory, Svobodny Ave., 79,

13 660041, Krasnoyarsk, Russian Federation

14 e Surgut State University, Lenin Str., 1, 628412, Surgut, Russian Federation

*Corresponding author

19 Gulzar T. Omurova

Kyrgyz National Agrarian University named after K.I.Skryabin, Mederov Str., 68, 720005,

21 Bishkek, Kyrgyz Republic

22 Email address: gulzar.omur@gmail.com

\section{Abstract}

Archaeological investigations in the forest-tundra zone of western Siberia are highly important for understanding the material culture, social structure and ethnic history of the indigenous population. Extraordinary preservation conditions for organic material in the frozen cultural layers favour the preservation of wooden material suitable for dendrochronological studies. During archaeological surveys in 2011 and 2012 in the Nadymskiy Gorodok settlement,

30 located in the forest-tundra zone in Yamalia, northwestern Siberia, 347 samples of construction 
timbers were taken and analyzed with dendroarchaeological methods. The main species are larch (Larix sibirica (Ledeb.)), spruce (Picea obovata (Ledeb.)) and pine (Pinus sibirica (Du Tour)). Methodical approaches that allow the determination of the source of the wood and correct dating of the time of the constructions are presented. The tree-ring dating of eleven buildings and parts of the palisade highlighting four periods of construction activity during the second half of the 15 th century (i.e. at around $1466 \mathrm{AD}$ and $1475 \mathrm{AD}$ ) and the first half of the 16th century (at the beginning of the 16th century and after 1530 AD). The results determine that only two wooden structures were built using wood from local forests. In all other cases, the distribution of the dendrochronological dates and timber provenance indicates the use of driftwood from forests further upstream of the Nadym River. Thus, for a precise determination of construction activity in the Nadymskiy Gorodok settlement, a long exposure time of the driftwood needs to be considered and previous presumptions about the settlement history revised.

Keywords: Dendroarchaeology, Dendroprovenance, Driftwood, Middles Ages, Northwestern Siberia, Settlement history

\section{Introduction}

Past archaeological excavations, accompanied by dendrochronological studies, have been carried out in the forest-tundra zone of western Siberia. These have provided insights into the settlement history from the Mesolithic to the Medieval period (Aleksashenko and Kosintsev, 2010; Goryachev et al., 2002; Gurskaya, 2008; Myglan and Vaganov, 2005; Shiyatov, 1980; Shiyatov et al., 2005; Sidorova et al., 2017). The investigations of the frozen cultural layers of settlements (e.g. Mangazeya, Polui (Obdosk), Ust Voykar, Bukhta Nahodka) significantly contributed to our knowledge of the material culture, social structure and ethnic composition of the indigenous population in this region (Gurskaya, 2008; Omurova et al., 2013; Shiyatov, 1980; Shiyatov et al., 2005; Sidorova et al., 2017). Since written sources about settlements in this region are scarce, archaeological remains are the only source of information about the settlement history and ethnic composition of the indigenous population in northern Siberia. Nadymskiy Gorodok (NG) is an exceptional medieval settlement, considered to be inhabited from the second half of 10th to beginning of 18th century and one of the administrative centers of the indigenous people in the subarctic zone in north-western Siberia, Russia (Goryachev et al., 2002; Shiyatov et 
62 al., 2005). Existing written documentary evidence about the history of NG settlement only 63 describe a later stage of its existence, from the time when western Siberia joined the Russian 64 State (from 1581 to 1598) (Kardash, 2009). The importance of the NG settlement lies in 65 providing unique information about the ethnic history of the indigenous inhabitants of the Lower $66 \mathrm{Ob}$ region, the history of Russian colonization of north-western Siberia in the 16th-17th 67 centuries and the history of geographical discoveries associated with the development of the Northern Sea Route.

The indigenous inhabitants were likely belonging to the Nenets (Samoyedic ethnic group) and the Khantys (also known as Ostyak; Ugrian ethnic group) or subgroups thereof (Forsyth, 1994; Kardash, 2013). Based on analyses of the zoological macro remains in the NG settlement 72 the indigenous inhabitants were mainly hunters (reindeer, arctic fox, sable, ermine, hare, 73 partridge), fisherman and partly reindeer breeders (Kosintsev, 2005). Yet interestingly, the 74 location of the NG settlement is not ideal for human habitation. The living conditions are harsh. 75 The nearby tributaries of the Nadym River are not abundant with fish; lichen pastures for animals are not available in the close proximity. At present, floods are very common during the summer season. In comparison, the islands in the close vicinity of the NG settlement are more suitable for habitation. It is assumed that one of the reasons for founding NG lies in its close proximity to the trade routes (Kardash, 2009). This is also reflected in the archaeological findings representing typical artifacts and goods of existing trade and barter in the north of western Siberia during the Middle Ages. In NG, the main imported goods were chain mail shirts, sabres, axes, cloths, silk, copper and silver jewelry (rings, pendants), ceramic vessels and copper pots (Kardash, 2009).

The prevailing permafrost in this area provides excellent preservation conditions for wooden material. Given that timber was the main building material, dendrochronological methods provide valuable insights into the history of the settlement, the history of the

87 constructions and the utilized tree species and their origin. Dendrochronology addresses a number of chronological issues - determining the dates of tree felling for primary constructions as well as periods of restoration (Chernych, 1996; Eckstein, 2007; Grabner et al., 2007; Shiyatov, 1980; van de Gevel et al., 2009).

91 The first dendrochronological results by Goryachev et al. (2002) assumed that the settlers 92 regularly used wood material from distant places of the settlement together with wood from other 
buildings, which they were able to re-use. In a more recent study by Omurova et al. (2013), the question about the origin of the wood for the settlement was not addressed and 78 samples were dated by the youngest end dates of the timbers, leading to misinterpretations of the construction activity. However, the question of dendroprovenance is obligatory for the correct interpretation of dendrochronological dates, as this may completely change the results obtained earlier. Thus, the identification of the origin of the timber is of high importance. At present, no coniferous trees suitable for building are growing in the area close to the settlement (Fig. 1). The closest larch forests are located $12 \mathrm{~km}$ to the west of the Nadym River, on the left bedrock coast, and $20 \mathrm{~km}$ upstream of the Nadym River (Goryachev et al., 2002). According to Hantemirov (2009), the present state of the polar timberline has remained unchanged since the Middle Ages. Owing to the lack of building material in the close surroundings, it is not clear which source of wood was used for the constructions in the NG settlement. The timber might have been harvested in distant forests or collected on the shorelines of the Nadym River. The latter refers to driftwood floated downstream the Nadym River and washed onto the shorelines. The observed variation in the dates of the last developed ring of the trees within and among the buildings, the presence of different stem dimensions, as identified by Goryachev et al. (2002) and Omurova et al. (2013), might be explained by the use of driftwood as the source for timber.

The above-mentioned uncertainties highlight the need for a critical evaluation of the so far identified periods of construction activity at the NG settlement. Here, the origin of wood would have fundamental importance for the interpretation of the dendrochronological dates. Further insights into the felling of the trees used for building as well as their origin can elucidate accompanying environmental changes, aspects related to the settlement history and timber use in the Siberian forest-tundra zone.

\section{Materials and methods}

\subsection{Study site}

The NG settlement is located in the Tyumen region, Yamal-Nenets autonomous district and lies $60 \mathrm{~km}$ to the north-west of the Nadym city and $25 \mathrm{~km}$ west of the Nadym River at $66.06^{\circ} \mathrm{N}$ and $71.97^{\circ} \mathrm{E}$ (Fig. 1a and b). The landscape is a typical forest-tundra (Fig. 2a) where tree growth is impaired by long cold winters (October to May) and warm but short summers with a mean July temperature of $14^{\circ}$ to $16^{\circ} \mathrm{C}$. Annual precipitation is about $500-600 \mathrm{~mm}$ and the 
124 highest rainfall amounts are observed in June. However, during the end of May and the 125 beginning of June when the snow and ice is melting, the water discharge of the Nadym River is 126 highest with average rates of $4490 \mathrm{~m}^{3} / \mathrm{s}$ and maximum rates of up to $6800 \mathrm{~m}^{3} / \mathrm{s}$.

127 This biome is characterized by a permanently frozen ground (i.e. permafrost) where only 128 the surface layer above the permafrost thaws during summer. The settlement is located at the 129 boundary of the arctic tundra and the subarctic forest-tundra with discontinuous permafrost 130 allowing tree species such as larch to form the northern timberline, followed southwards by 131 spruce and pine (Fig. 1b).

132 The settlement was established on a small island within the delta of the Nadym River and 133 stretches in a northwesterly to southeasterly direction (Fig. 2b). The island is formed by the 134 merger of two narrow (up to $30 \mathrm{~m}$ ) ducts, which connects the floodplain lake system with a river. 135 NG has a rectangular shape which is $80 \mathrm{~m}$ long and $25 \mathrm{~m}$ wide, thereby comprising $2000 \mathrm{~m}^{2}$. The 136 NG settlement was surrounded by a wooden palisade with a preserved entrance facing northwest. 137 From this a central passage divides the oval shaped settlement into two equal halves. The 138 rectangular constructions vary in size (from $1.4 \times 1.2 \mathrm{~m}$ to $8.5 \times 7.5 \mathrm{~m}$ ) indicating different 139 functions such as residential or utility buildings. At present, the southeastern side of the NG 140 settlement is further subsiding under the influence of natural factors such as thawing of the 141 permafrost and erosion of the shoreline (Kardash, 2009) (Fig. 2c and d). 


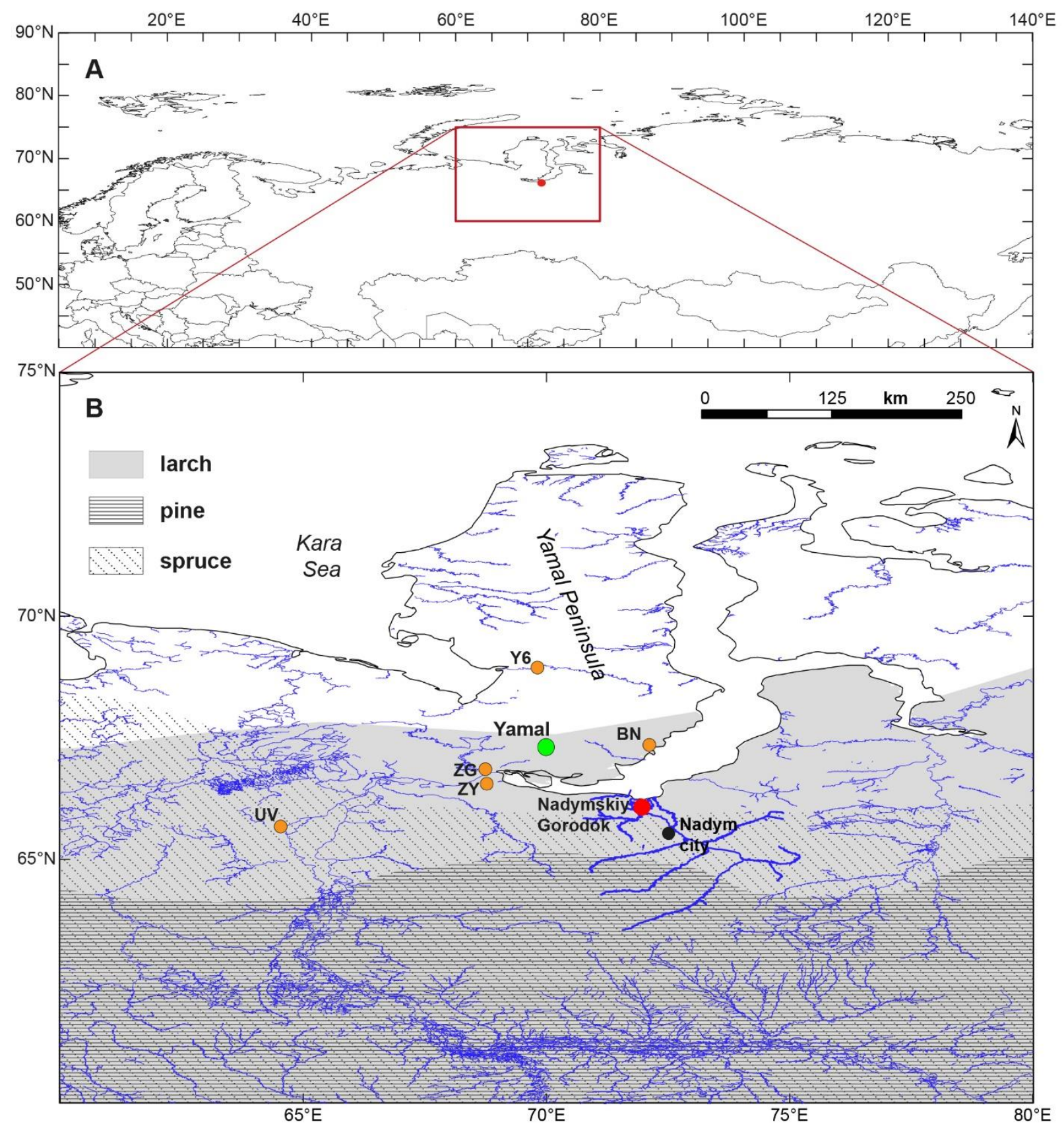

Fig. 1. Location of the archaeological site Nadymskiy Gorodok (red dot) in northwestern Siberia 145 (A and B). (B) The settlement is situated in the delta of the Nadym River (bold blue lines), in 146 close vicinity to the Nadym city (black dot) and the site location of the material included in the 147 Yamal reference chronology (green dot). Known places of past human activity (orange dots):

148 Yarte 6 settlement (Y6), Buchta Nakhodka settlement (BN), Zelenaya Gorka settlement (ZG), 149 Zelenyi Yar burial site (ZY), Ust-Voikar settlement (UV). Present distribution of larch, pine and 150 spruce forests in this region is shown (see legend for different species). 

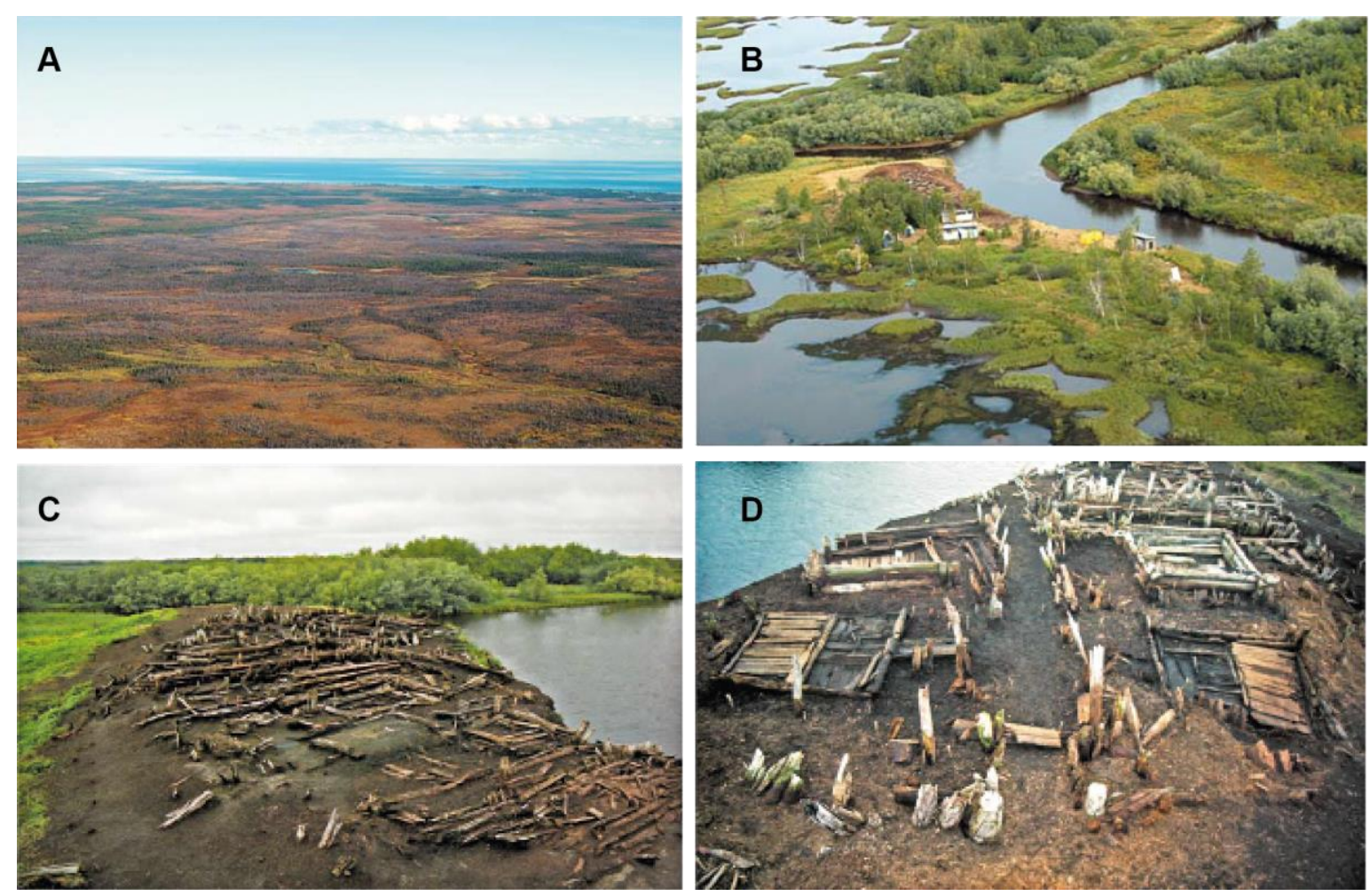

153

154

Fig. 2. Typical forest-tundra landscape (A) characterizes (B) the location of the NG settlement on a small-elevated island (C) in the delta of the Nadym River. Wooden constructions (C and D) are well preserved under permafrost conditions (Photos from Kardash, 2009).

\subsection{Sampling, wood identification and tree-ring measurements}

The NG settlement is a wooden multi-layer archaeological monument and ongoing archaeological excavations have been carried out since 1998. The presence of permafrost allowed the wooden structures to remain well preserved. The cultural layer has a maximum thickness of up to $3.5 \mathrm{~m}$ at the centre of the settlement but gradually decreases towards the periphery (Fig. $2 \mathrm{c}$ and d). The wooden buildings showed different degrees of preservation at the time of sampling. Some of these structures remained in their original state in situ, some were already disassembled, and the timber was displaced during the excavations. However, a clear allocation of the individual timber could not be entirely reconstructed for some buildings (e.g. for construction 10). In the latter case, the availability of markers on samples allowed us to trace the samples to its original building and its intended use (e.g., floors, walls, etc.).

During 2011 and 2012, 347 samples from wooden constructions were collected from eleven buildings as well as from parts of the palisade of the NG settlement (Table 1 and 
170

171

172

173

174

175

176

177

178

179

180

181

182

183

184

185

186

187

188

189

190

191

192

193

194

195

196

197

198

199

supplementary Table S1). From each element of wooden structure, we selected a minimum of two samples that showed the maximum number of peripheral rings. The information provided by the archaeologists was used for describing the individual buildings, parts of the palisade and the attribution of individual elements. Architectural terms (log cabin, plank, etc.) are given here according to Plujnikov (1995). A detailed description of the samples for each building is provided in Table 1 and supplementary Table S1.

The species of all sampled timbers were microscopically identified using wood anatomical features (Benkova and Schweingruber, 2004; Schweingruber, 1990) before measuring the treering widths. Three tree species were identified: larch, spruce and pine. The differentiation between larch and spruce proved to be very challenging. The distinction between the two species was beside standard wood anatomical features additionally based on the shape of the borders of the pits in the radial section as described by Bartholin (1979). Larch was identified based on the following characteristics: presence of heartwood, abrupt early-latewood transition, 5-6-angled shape of early wood tracheids and smooth shape of exterior borders of pits in ray tracheids in the radial section. Wood anatomical features for spruce include absence of heartwood, gradual earlylatewood transition, and right-angled shape of early wood tracheids and angular-shaped border of pits in ray tracheids in the radial section. The wood structure of pine shows the presence of resin canals and large pinoid pits in rays and smooth ray tracheid walls in the radial section (Benkova and Schweingruber, 2004).

The measurement of the annual growth rings of each sample was done with an accuracy of $0.01 \mathrm{~mm}$ using the measuring station LINTAB 5. The calendar dating of the measured tree-ring width series was based on visual cross-dating (i.e. visually matching sequences of growth patterns) (Douglass, 1919) and cross-correlation analyzes using DPL (Holmes, 1994) and TSAP V3.5 (Rinn, 1996). The best overlapping position was statistically evaluated using the Student's t-test with adaptations after Hollstein (1980) (THO) and the year-to-year synchronicity ("Gleichläufigkeit" (GLK)). Pearson correlation coefficients (r) for the common period 1120$1507 \mathrm{AD}$ were calculated on standardized tree-ring chronology versions after removing the age trend in each tree-ring series. This was done by applying a cubic smoothing spline function at a frequency cut-off at two third of the length of each individual tree-ring series using the ARSTAN program (Cook and Krusic, 2008). 
As a first step, tree-ring width (TRW) measurements were cross-dated for each species

\begin{tabular}{|c|c|c|c|c|c|c|c|c|c|c|c|c|c|c|c|}
\hline \multirow{4}{*}{ 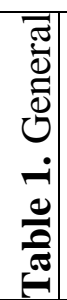 } & & \multirow{4}{*}{ 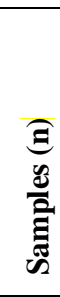 } & \multirow{2}{*}{\multicolumn{3}{|c|}{$\begin{array}{c}\text { Distribution by } \\
\text { species } \\
\text { composition, \% }\end{array}$}} & \multirow{2}{*}{\multicolumn{5}{|c|}{$\begin{array}{l}\text { Distribution by types of } \\
\text { building elements, \% }\end{array}$}} & \multicolumn{4}{|c|}{ Periods of construction activity, } & \\
\hline & & & & & & & & & & & & & & 203 & arat \\
\hline & & & \multirow[b]{2}{*}{ ప્ప } & \multirow[b]{2}{*}{ 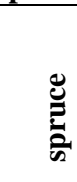 } & \multirow[b]{2}{*}{. } & \multicolumn{3}{|c|}{ wall } & \multicolumn{2}{|c|}{ floor } & \multirow[b]{2}{*}{ I } & \multirow[b]{2}{*}{ II } & \multirow[b]{2}{*}{ III } & \multirow{2}{*}{$\begin{array}{l}204 \\
205 \\
\end{array}$} & \\
\hline & & & & & & $\stackrel{0}{0}$ & 壹 & 荹 & 岌 & 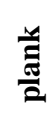 & & & & & and \\
\hline \multirow{14}{*}{ 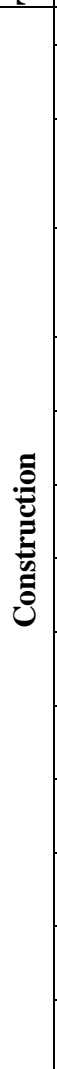 } & 2 & & & & & & & & & & & & & & \\
\hline & $\begin{array}{l}5.30-5.70 \\
\text { m a.s.l. }\end{array}$ & 11 & 18 & 36 & 46 & & 36 & 64 & & & & & $\begin{array}{l}\text { after } \\
1519 \\
\end{array}$ & 207 & \\
\hline & $\begin{array}{l}4.90-5.00 \\
\text { m a.s.l. }\end{array}$ & 24 & 38 & 29 & 33 & 33 & 22 & 45 & 7 & 93 & & & $\begin{array}{l}\text { after } \\
1507\end{array}$ & $\begin{array}{l}208 \\
209\end{array}$ & $\begin{array}{l}\mathrm{rc} \\
\mathrm{e}\end{array}$ \\
\hline & $\begin{array}{l}4.98-4.72 \\
\text { m a.s.l. }\end{array}$ & 12 & 50 & 33 & 17 & & 25 & 75 & & & & $\begin{array}{l}\text { after } \\
1484\end{array}$ & & 210 & \\
\hline & 3 & 13 & 31 & 38 & 31 & 100 & & & & 100 & & $\begin{array}{l}\text { after } \\
1479 \\
\end{array}$ & & 211 & \\
\hline & 6 & 37 & 43 & 22 & 35 & 100 & & & & 100 & & & $\begin{array}{l}\text { after } \\
1486\end{array}$ & 212 & \\
\hline & 7 & 37 & 76 & 8 & 16 & & 47 & 53 & 5 & 95 & & $\begin{array}{l}\text { after } \\
1477 \\
\end{array}$ & & 213 & ies \\
\hline & 10 & 35 & 17 & 74 & 9 & 80 & 14 & 6 & & & $\sim 1465$ & $\sim 1475$ & & $\begin{array}{l}\text { aldit4 } \\
1531\end{array}$ & \\
\hline & 11 & 12 & 42 & 25 & 33 & 67 & & 33 & 67 & 33 & $\begin{array}{l}\text { after } \\
1466 \\
\end{array}$ & & & 215 & e \\
\hline & 12 & 21 & 38 & 19 & 43 & 83 & & 17 & & 100 & $\begin{array}{l}\text { after } \\
1449\end{array}$ & & & 216 & \\
\hline & 14 & 17 & 24 & 29 & 47 & 40 & 40 & 20 & 10 & 90 & & $\begin{array}{r}\text { after } \\
1472 \\
\end{array}$ & & 217 & \\
\hline & 17 & 6 & & 100 & & 67 & 33 & & & & $\sim 1465$ & & & 218 & \\
\hline & 18 & 1 & & & & & & & & & $\sim 1429$ & & & 219 & \\
\hline & 19 & 1 & & & & & & & & & & & $\begin{array}{l}\text { after } \\
1511 \\
\end{array}$ & 220 & \\
\hline \multirow{4}{*}{ 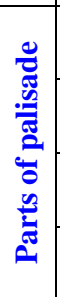 } & WFP & 5 & 20 & 20 & 60 & 20 & 60 & 20 & & & & & & $\begin{array}{l}\text { aftert } \\
1559\end{array}$ & \\
\hline & PNNWE & 8 & 12 & 38 & 50 & 63 & 25 & 12 & & & & $\begin{array}{l}\text { after } \\
1482 \\
\end{array}$ & & 222 & \\
\hline & NWE & 15 & 73 & 7 & 20 & 87 & & 13 & & & & & & after3 & \\
\hline & POC $6 \& 7$ & 16 & 31 & 56 & 13 & 6 & 13 & 81 & & & $\begin{array}{l}\text { after } \\
1456 \\
\end{array}$ & & & & \\
\hline
\end{tabular}

$226 \mathrm{y}$ and statistically matching TRW series. Those species-specific raw mean chronologies were

227 furthermore compared to each other. Secondly, absolute calendar dates for the TRW series were 228 obtained by cross-dating them to the 2770-year long larch chronology covering the period 764 229 BC to 2005 AD developed for the Yamal Peninsula (Briffa et al., 2013; Hantemirov, 2009) (Fig. 230 1b). This data is publicly accessible at the International Tree Ring Data Bank (National Oceanic 
231

232

233

234

235

236

237

238

239

240

241

242

243

244

245

246

247

248

249

250

251

252

253

254

255

256

257

258

259

260

261

and Atmospheric Administration (NOAA), 2017). For the period 950 - 1650 AD, a minimum number of 27 (at around 1190 AD) and a maximum of 155 (at 1963 AD) samples are included in this reference. For pine and spruce, long TRW chronologies, which could be used as independent references, are lacking for this region.

Despite a careful sample selection, the individual wood samples showed different degrees of preservation. To obtain an absolute dating, three groups of dating regarding their precision were established: 1) for samples having an outermost ring with bark, the exact year and season of the felling for the trees (i.e. waney edge dating); 2) for samples that had maximum 10 absent rings (towards the bark) an estimation of the felling was conducted (following (Kardash et al., 2018)) (group < 10 rings; here used as sapwood dating); 3) for samples with more than 10 absent rings (group > 10 rings) and which showed traces of hewing, a heartwood dating was done providing an earliest possible felling date of the tree (post terminus quem). For determining the time of the wooden buildings, we focused on the felling dates of the utilized trees, i.e. felling date derived via sapwood and waney edge dating. This approach allowed for the exclusion of a considerable array of dates from poorly preserved samples. Consequently, it was possible to more accurately delineate the period of the existence of the individual buildings. The identification of the origin of the utilized trees was performed on a set of different criteria that allowed us to distinguish between logged and drifted material.

The first criterion considers the felling dates of the trees (though driftwood was not purposely felled, we use the term felling date throughout). In the best case, the waney edge was present and the determination of the felling year and season of the utilized trees was possible. Since driftwood might be a timber source for the wooden buildings, we focused on felling dates that occurred within a short time period, i.e. in the same year.

The second criterion involves the type of timber, its dimensions and the context of the construction. For example, logs used as walls of the buildings should be similar in diameter to simplify the subsequent task of fitting logs in a log cabin.

The third criterion involves the tree species. We assumed that pine and spruce trees are easier to float since larch, compared to the other species, is heavier due to a higher bulk density and resin content (Chudinov et al., 1965). If the building material does not meet the criteria listed above, we assumed the use of driftwood in the building process. Whenever this is the case, the constructions are dated by the most recent dendrochronological date of all samples within a 
262

263

264

265

266

267

268

269

270

271

272

273

274

275

276

277

278

279

280

281

282

283

284

285

286

287

288

289

290

291

building. We dated timber of the floors separately because the date is normally not connected with the dates of the walls, likely being laid (or re-laid) at any time.

\section{Results}

\subsection{Sample overview, tree species and timber types}

A total number of 271 timbers from eleven buildings and parts of the palisade that were suitable for measuring the TRW were wood anatomically analyzed (Table 1 and supplementary Table S1). Results show that three tree species were used and that they occurred in roughly equal proportions: larch 39\% (106 samples), spruce 33\% (90 samples), and pine 28\% (75 samples) (Fig. 3).

The amount of analyzed timbers taken from each building varies ranging from one (construction 18 and 19) to 37 (construction 6 and 7) samples. Construction 2 consists of different excavated levels. In total 47 samples were analyzed from this building (Table 1). An equal distribution of wood species was found for most buildings, except for construction 7, where larch was used predominantly (76\% of the samples). For construction 10 ( $74 \%$ of the samples) and 17 (all samples), spruce was the main species. Interesting results are obtained for the utilized species of construction 2 with larch being twice as frequent in the lower (older) and pine in the upper (younger) level.

The number of measured rings, i.e. age distribution, of the samples showed similar results for the wooden buildings and parts of the palisade with spruce dominating the age class of up to 100 years (Fig. 3a and b). Mainly larch trees are found in the age class of 101 to 200 years whereas all samples with more than 200 rings are pines (Fig. 3a and b). The typological analysis of the timbers from the NG settlement showed that for the walls of the buildings, mainly logs were used (construction 3, 6, 10, 11, 12 and 17). Planks and half-logs (construction 2 and 7) as well as logs and half-logs (construction 14) were only occasionally used (Table 1). For flooring, predominantly planks and, in some cases, half-logs (construction 11) were utilized as well as parts of boats (construction 14) (supplementary Table S1). Regarding different elements within the settlement, logs and half-logs used within the buildings were made from spruce trees whereas larch, followed by spruce, were the main tree species for planks. However, logs for the palisade were mainly taken from larch trees whereas planks were made from spruce trees (Fig. $3 \mathrm{c}$ and d). 

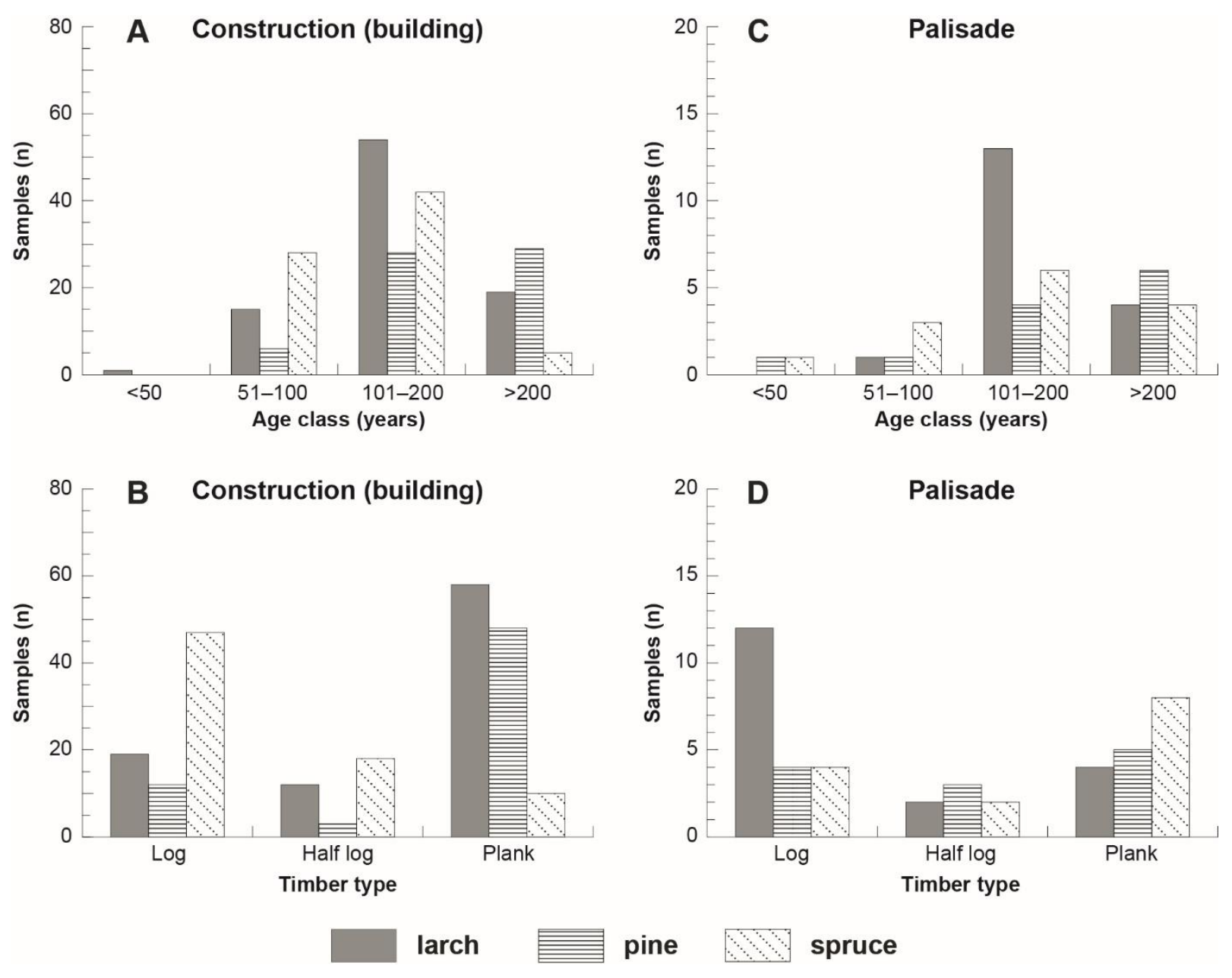

pine

293 Fig. 3. Age class and type for the timber used (A) and (B) in the constructions (buildings) and 294 (C) and (D) for the palisade, respectively (please note differences in X-axis). Different shadings 295 for the species are shown in the legend.

\subsection{Chronology development}

298 In total, 271 samples were dated absolutely, whereas ring-width measurements of 76 299 samples were excluded from the analyses as they contained less than 60 rings, reaction wood and 300 poor preservation. The dated larch samples lead to the development of a larch chronology 301 covering 542 years from 1075 to 1616 AD (Fig. 4). The mean correlation between all larch TRW 302 series is $r=0.64$ and the mean segment length is 162 years. A total of 75 pines were dated and a 303 550-year long pine chronology, covering the period 1010-1559 AD, was developed. The inter304 series correlation is $r=0.57$ and the average length of the pine samples is 194 years. 
Finally, 90 spruce samples produced a 388-year long chronology (1120-1507 AD). All

306 spruce samples correlated with $r=0.54$ to each other and the average segment length is 126

307 years. Samples from all three species showed identical annual growth rates of 0.52 to $0.53 \mathrm{~mm} /$ 308 year (Fig. 4).
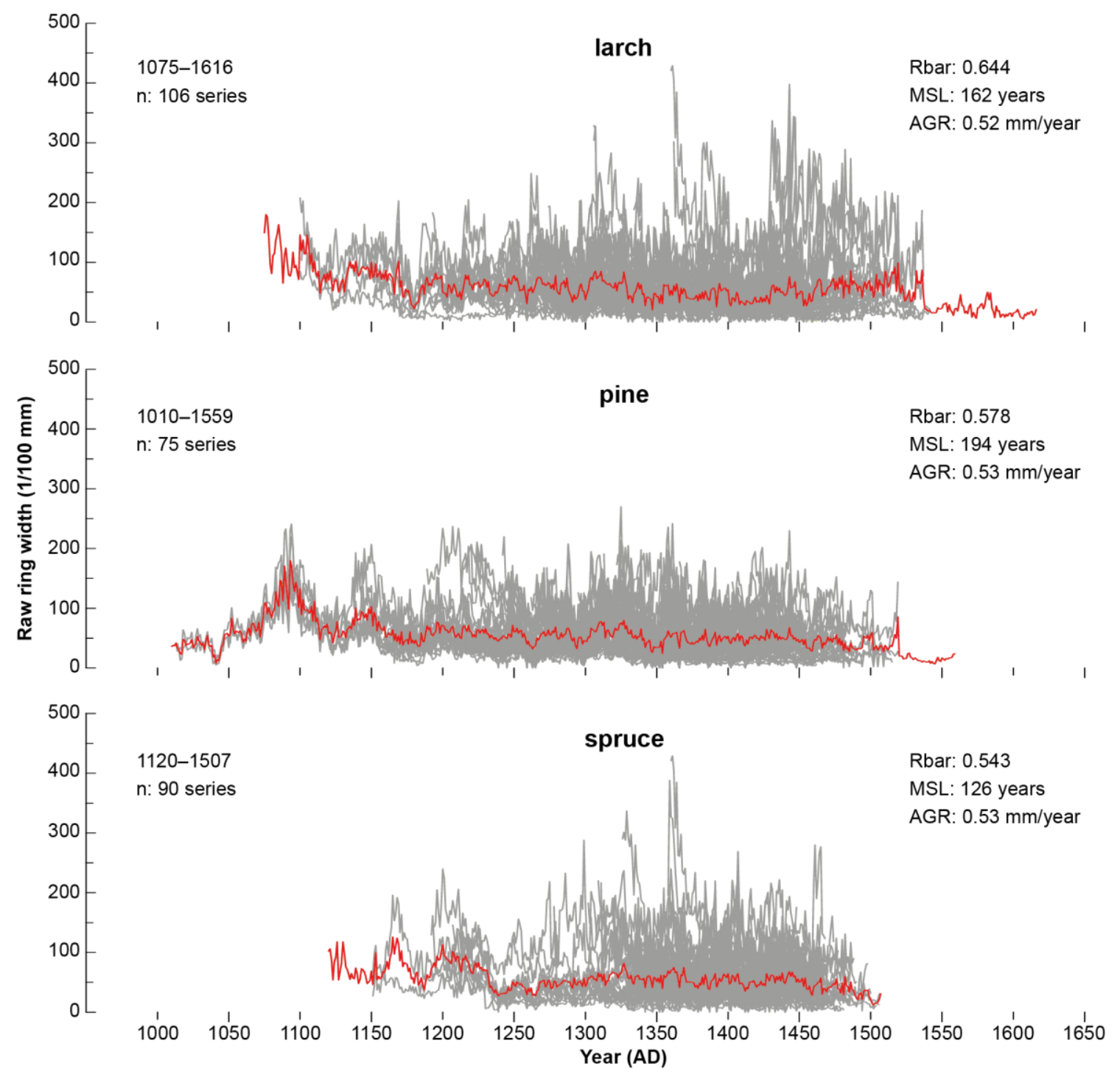

310 Fig. 4. Overview of dated raw tree-ring measurements for larch, pine and spruce and their 311 respective mean (i.e., species) chronologies (red). The full time span of the chronology and the 312 number of samples (n) are provided along with the inter-series correlation (Rbar), mean segment 313 length (MSL) and AGR describing the annual average growth rates.

Based on the raw TRW chronologies, all three species showed very similar growth patterns, expressed by correlation values exceeding the $99.9 \%$ confidence level. The highest 
317 correlations were obtained for the raw spruce and pine TRW chronologies exceeding a t-value of $31819($ THO $=19.40)$ with a GLK of $72.40 \%$. This is followed by the correlations of larch and 319 spruce TRW chronologies $(\mathrm{THO}=16.80$, GLK $=72 \%)$ and the larch and pine TRW 320 chronologies $(\mathrm{THO}=15.0, \mathrm{GLK}=70.30 \%)$.

321 The standardized chronology versions for each species in synchronized position to the 322 Yamal reference are shown in Figure 5. Interestingly, the highest correlation was found between 323 the spruce and Yamal larch reference with a t-value of 13.0 (THO) and a GLK of 69.50\%. The 324 second highest correlation was found for the larch TRW chronology with THO of 10.70 and a 325 GLK of $64.90 \%$ whereas pine still significantly (at the $99.9 \%$ level) correlated with THO of 3269.73 and a GLK of $63.0 \%$. For the overall common period 1120-1507 AD, correlation 327 coefficients between the detrended species-specific chronologies range from 0.45 (spruce and 328 larch) to 0.61 (pine and larch) (Fig. 5). Correlation values for the individual species chronologies 329 to the Yamal reference is lowest, yet significant, for spruce $(\mathrm{r}=0.34)$ and highest for larch $(\mathrm{r}=$ 330 0.51) (all p < 0.001). Averaging all samples, a new NG_composite chronology covering the period 1010 to $3321616 \mathrm{AD}$ was developed.

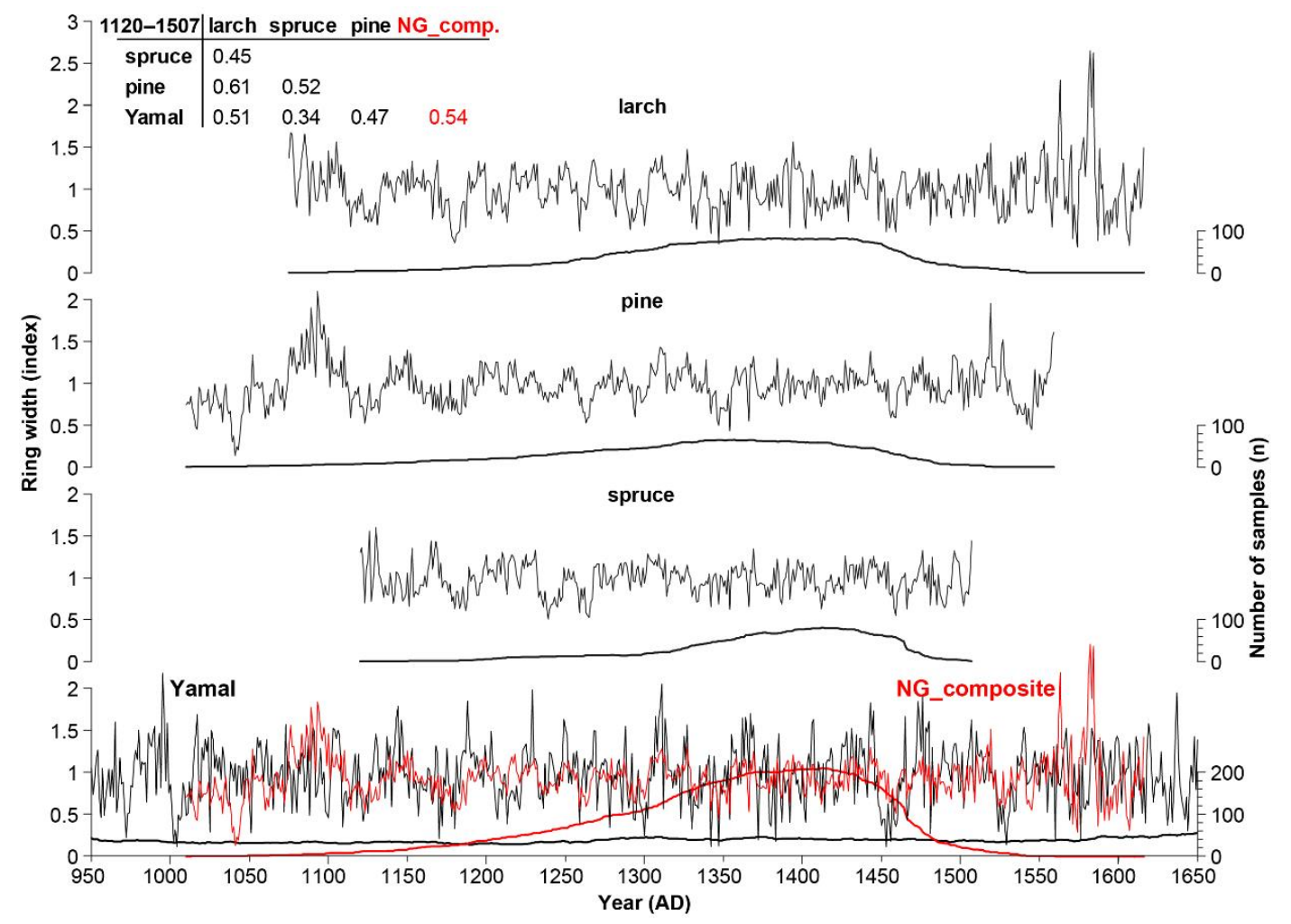


Fig. 5. Detrended species chronologies for larch, pine and spruce in overlapping position to the Yamal larch reference chronology. Correlation values are provided for the common period 1120-1507 AD (all exceeding the 99.9\% significance level).

\subsection{Dating of the NG settlement}

Our dendrochronological dating results show the wide range of felling dates or dates obtained based on sapwood dating (Fig. 6; Table 1 and supplementary Table S1). For the three excavated levels (i.e. geodetic altitudes in the Baltic elevation system, i.e. from the Baltic Sea level) of construction 2, the following results were obtained: For the upper (5.30-5.70 m a.s.1.) level, 11 samples (half-logs and planks) representing elements of the walls, were dated. These timbers, however, were removed from its original position prior to sampling. Felling dates range from 1365 (ng69), 1464 (ng71) to 1481 (ng70) and for samples with up to 10 absent rings, felling dates were estimated to 1464 (ng85a), 1514 (ng82) and 1519 (ng62). For sample ng64, a felling date of $1616 \mathrm{AD}$ was obtained. Most likely this sample was re-located or mistakenly attributed to upper level. The upper level of construction 2 was built after 1519 AD. The construction preserved at the middle level (4.90-5.00 m a.s.l.), consisting of 24 samples and including all types of timber for the walls and floor, revealed a latest felling date of $1507 \mathrm{AD}$ (sample ng161). For the lowest and thus oldest level (4.72-4.98 m a.s.1.), 12 samples (half-logs and planks) were dated that belong to the northwestern wall. A wide time span of felling dates was obtained that range from 1439 (sample ng129) to 1484 (sample ng119) whereas a waney edge dating of one sample (ng127) revealed a tree felling in 1465 AD. An accumulation of felling dates between 1482 and 1484 (three samples) indicate building activity after 1484 AD. It can be concluded that the first building was constructed after 1484 and that it was twice rebuilt: after 1507 and after 1519 AD. Here, the number of doorsteps (three in total) corresponds to the number of the levels (i.e. periods of construction activity).

For construction 3, out of 18 samples preserved in situ, 13 samples were dated. All three species were used equally. The walls consisted only of logs that showed felling dates between 1281 (ng463) and 1479 (ng455) whereas for the floor only planks from trees felled between 1329 and 1475 were utilized. Therefore, the building was built after 1479 AD, likely using driftwood as the main resource. 
Samples for construction 6 were preserved in situ and from 45 analyzed samples, 36 could

be absolutely dated. Similar to construction 3, the likely use of driftwood provided a wide range of felling dates whereas a waney edge dating was possible for seven logs of the walls ranging from 1444 to 1477 AD (supplementary Table S1). Another tree used as log for a corner joint was felled in 1486 AD. In addition, for a plank from the floor an earliest possible felling date of after $1492 \mathrm{AD}$ was obtained. The time of building is likely in or after 1486 with a possible repair of the flooring after $1492 \mathrm{AD}$.

For construction 7, a total of 37 samples, found in situ, were dated. The majority of the samples were planks and half-logs and identified as larch, of which four samples had a waney edge preserved. Their felling dates were 1468 AD (sample ng246; doorsill in SW wall), 1474 AD (sample ng232; floor along NE wall), 1477 AD (sample ng251, SW wall), and 1531 AD (sample ng080; floor). A distinct feature of construction 7 was the presence of five doorsteps (samples ng245 (after 1460 AD), ng246 (1468 AD), ng244 (c. 1473 AD), ng243 (c. 1500 AD), ng079 (c. 1523 AD)) indicating several phases of repair. The time between the building of the first and fifth doorsteps was at least ca. 55 years and the time of replacement of each doorstep was about 14 to 16 years.

The timber for construction 10 was not sampled in situ. 35 samples out of 43 were dated. The majority of the samples are spruce and are mainly logs with a similar diameter. Two periods of tree felling were identified: $1465 \mathrm{AD}$ (ten samples from the SW wall) to $1466 \mathrm{AD}$ (seven samples from the NW wall) and $1474 \mathrm{AD}$ (four samples from the $\mathrm{SW}$ wall) to $1476 \mathrm{AD}$ (four samples from the NW wall). The narrow timeframe of the felling dates points to a deliberate harvest of the trees. One larch log which was hewed on both sides was estimated to be felled at around 1531 AD. Overall, three periods of constructions were identified for construction 10: c. 1465, c. 1475 and after 1531 AD (sample ng083, larch log in SW wall) (supplementary Table $\mathrm{S} 1)$.

Construction 11 was not preserved in situ. 20 samples were taken, of which 12 could be dated. The walls and interior partition were made of logs. The floor consisted of half-logs and planks. Only sapwood datings were possible and individual elements were dated to between ca. 1461 AD (ng474, internal partition) and ca. 1466 AD (ng294, NW wall). Thus, the construction was built not earlier than 1466 AD. 
Half of construction 12 was destroyed by the erosion of the riverbank (Fig. 7) and evidence of fire were found in the northwestern part. In total, 24 samples were analyzed and 21 were successfully dated (supplementary Table S1). The presence of outermost rings on two spruce samples (logs) for the SW wall revealed felling dates of 1422 AD (ng329) and 1427 AD (ng 328). Traces of hewing were found on a pine sample (ng331) where the last measured ring was dated to around $1449 \mathrm{AD}$. On one out of 15 floor planks, a sapwood dating was possible and the tree was estimated to be felled c. 1466. The usage of logs likely indicates driftwood and the time of building is estimated to be around 1449 AD.

Construction 14 was disassembled prior to sampling and 17 out of 24 samples were dated. For one spruce log and one half-log for the SW wall a sapwood dating of ca. 1468 AD (ng306) and ca. 1469 AD (ng275) was obtained. A heartwood dating of floor planks, likely re-used from ships or boats, was established for three samples and the felling dates are after 1446 (ng286), after 1457 (ng284) and after 1465 AD (ng285). The building was likely built in ca. 1469/ 1472 $\mathrm{AD}$ (wall). A repair of the flooring was done ca. 1518 AD.

Construction 17 has been preserved in situ and seven samples were taken from the remnants of the log cabin, of which six were successfully dated. The main building materials were logs from spruce trees of similar diameter, of which four were felled in 1464 and 1465 AD. This close range of the felling indicates purposeful logging activity and the building of the cabin with wood felled 1464/1465 AD.

For construction 18 and 19, only one sample (a log) each was analyzed. Both samples had the outermost ring preserved. The pine tree used for construction 18 felled in 1429 AD and of the larch tree for construction 19 in 1511 AD.

To conclude, four main periods of construction activity in the NG settlement were identified based on the obtained felling dates of the trees used for the buildings: 1. around 1466 $\mathrm{AD}$; 2. around $1475 \mathrm{AD} ; 3$. beginning of the 16th century; and 4. after $1530 \mathrm{AD}$. Most of the buildings were built in the second half of the 15th century and then subsequently repaired.

Additionally to the remnants of individual buildings, a total of 58 samples from parts of the palisade of the NG settlement, not preserved in situ, were analyzed and 44 samples could be dated (Table 1 and supplementary Table S1). Sixteen samples (13 planks) from the palisade opposite constructions 6 and 7 were dated. The obtained sapwood dates range from around 1391 (ng132) to around $1456 \mathrm{AD}$ (ng135). Trees used for the palisade near the north-west entrance 
426 (PNWE) was estimated to be felled around 1482 (sample ng261; pine log). Fifteen timbers

427 (mainly logs and from larch trees) were dated for the palisade at the north-west entrance (NWE).

428 On four samples, the waney edge was present and the dating ranged from 1497 (ng501), 1536

429 (ng505) to 1537 AD (ng500) for the frame of the entrance element, and 1541 AD (ng175) for a

430 hewn log. For the western frame of the palisade (WFP), five samples were dated and two periods

431 of construction were found. A spruce half-log (ng298) was felled after 1479 AD and a pine half-

$432 \log ($ ng194) after 1559 AD.

433
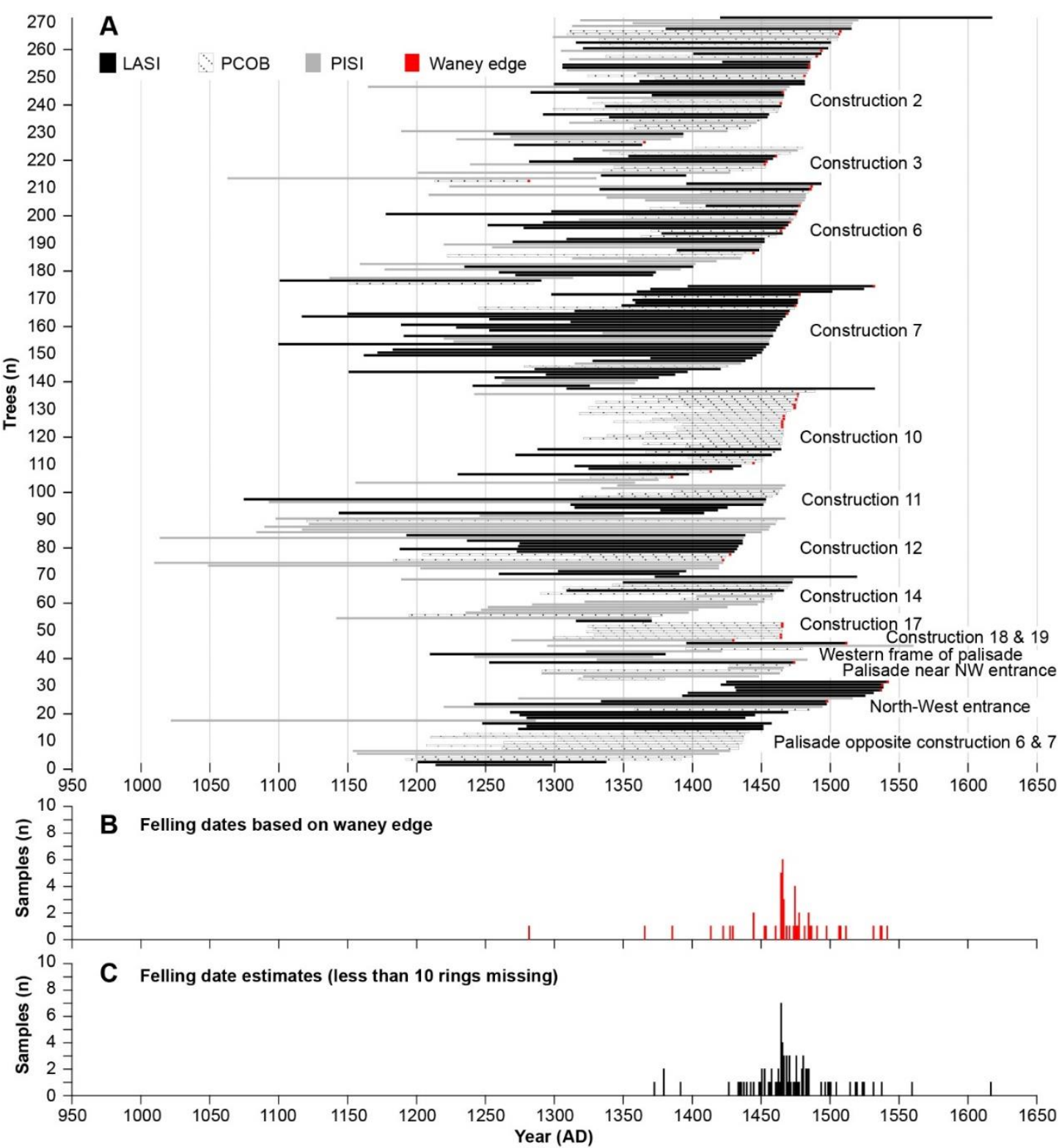
435

436

437

438

439

440

441

442

443

444

445

446

447

448

449

450

451

452

453

454

455

456

457

458

459

460

461

462

463

464

Fig. 6. Sample replication for each building and parts of the palisade including the species (see legend for colors codes) and presence of the waney edge (red) (A) together with their end dates of the felling (B) and sapwood estimates for samples with less than 10 rings missing (C).

\section{Discussion}

\subsection{Tree growth and chronology development}

Samples from all three species showed almost identical annual growth rates of 0.52/0.53 $\mathrm{mm} /$ year (Fig. 5). This slow tree growth reflects the harsh climate conditions in this region. In addition to the high inter-species correlations, significant correlation results were found individually for all species chronologies to the Yamal reference chronology (Hantemirov and Shiyatov, 2002; Shiyatov and Hantemirov, 2000). At northern treelines, tree growth is limited by summer air temperatures (Shiyatov and Hantemirov, 2000), leading to synchronous growth patterns across the species and thus, justifying the development of composite TRW chronologies. Specifically, Hantemirov and Shiyatov (2002) presented a spruce-larch composite chronology which showed positive correlations of tree growth to June and especially July temperatures. This summer temperature sensitivity of the trees lead to coherent growth pattern over large distances in the northern boreal forests and significant agreements in the ring-width patterns were identified to range up to $300 \mathrm{~km}$ (Vaganov et al. 1996; Hellmann et al. 2016). This also explains the high success rate of the cross-dating of the samples within but also between the tree species in this region.

The development of composite chronologies including different species and thereby covering multiple centuries and even millennia is also shown for high altitudes, e.g. the European (Nicolussi et al., 2009) and opens up new possibilities to study human and climate history in the future.

\subsection{Periods of construction activity and utilized wood}

A first period of construction activity was identified at around $1465 \mathrm{AD}$ including the constructions 10,11, 12, 17 and 18 (Fig. 6 and 7). Only for the constructions 10 and 17, a deliberate felling of the trees from nearby forests for building material was proven and the time of building reliably determined. Both buildings were erected using mainly spruce trees with 
similar diameters during the first period of construction activity at around 1465 AD (Fig. 6). Moreover, even with the presence of a wide range of obtained felling dates (Fig. 6), we were able to determine three more periods of construction in addition to the first period of construction activity: at around 1475 AD (constructions 2, 3, 7, 14 and re-building of construction 10), beginning of the 16th century (constructions 6 and 19), and after 1530 AD (re-building constructions 7 and 10) (Fig. 6 and 7, Table 1 and supplementary Table S1). The building material for the majority of the buildings and the walls showed a high variety of utilized tree species, tree age (Fig. 3), and obtained felling dates suggesting an origin of the utilized material from driftwood and thus, a mainly unknown location.

It is known that driftwood is a widely used resource for building material and other wooden objects in regions were forests are scarce or even absent as for example in Scotland, Iceland, Greenland or northern North America, (e.g. Alix and Brewster, 2004; Dickson 1992; Griebel, 2013; Kristjansdóttir et al., 2001). For the NG settlement, the source region of the driftwood is likely to be upstream (i.e., further south) of up to $200-250 \mathrm{~km}$ distance along the Nadym River. The uprooted trees were drifting downstream between the end of May - beginning of June when the highest discharge of the Nadym river is recorded due to snow and ice melt or during significant flood events. A southern source region of the driftwood is apparent as the tree species pine and spruce were most present, totaling two-third of all dated samples and their natural distribution limit of both species is located south of the NG settlement (Fig. 1). It can be assumed that the present northern treeline has not changed significantly during medieval times (Kharuk et.al., 2004; Vaganov E.A. and Shiyatov S.G., 2005) as no exceptionally high temperatures were observed in a temperature reconstruction for the Yamal peninsula based on tree-ring width and maximum latewood density data (Hantemirov and Shiyatov, 2002; Briffa et al., 2013). Moreover, the use of driftwood is supported by recent findings by Omurova et al. (2018) that addressed anatomical modifications in the tree-ring structure such as frost rings, light rings, and fluctuations of the wood density and missing tree rings in the timber from the NG settlement and living tree samples. Results showed that anomalies in living trees growing $20 \mathrm{~km}$ south of NG were significantly higher than in the archaeological material from the NG settlement (Omurova et al., 2018) indicating that the trees used as building material originated from regions further south where the growing conditions are more favorable and the probability of springsummer frosts is much lower. Regarding the wide range of felling dates, for example for 
496 construction 3, a remarkable difference of almost 180 years between the oldest (1281 AD) and 497 youngest (1460 AD) tree felling were identified (i.e. waney edge dating). This cannot be 498 explained by the re-use of timber alone. Only in one case, i.e. the flooring of construction 14, we 499 were able to identify re-used timber. In addition, the presence of permafrost in which the lower 500 elements of the buildings are embedded, i.e. frozen into the ground, imposes very large 501 restrictions for the re-use of wood.

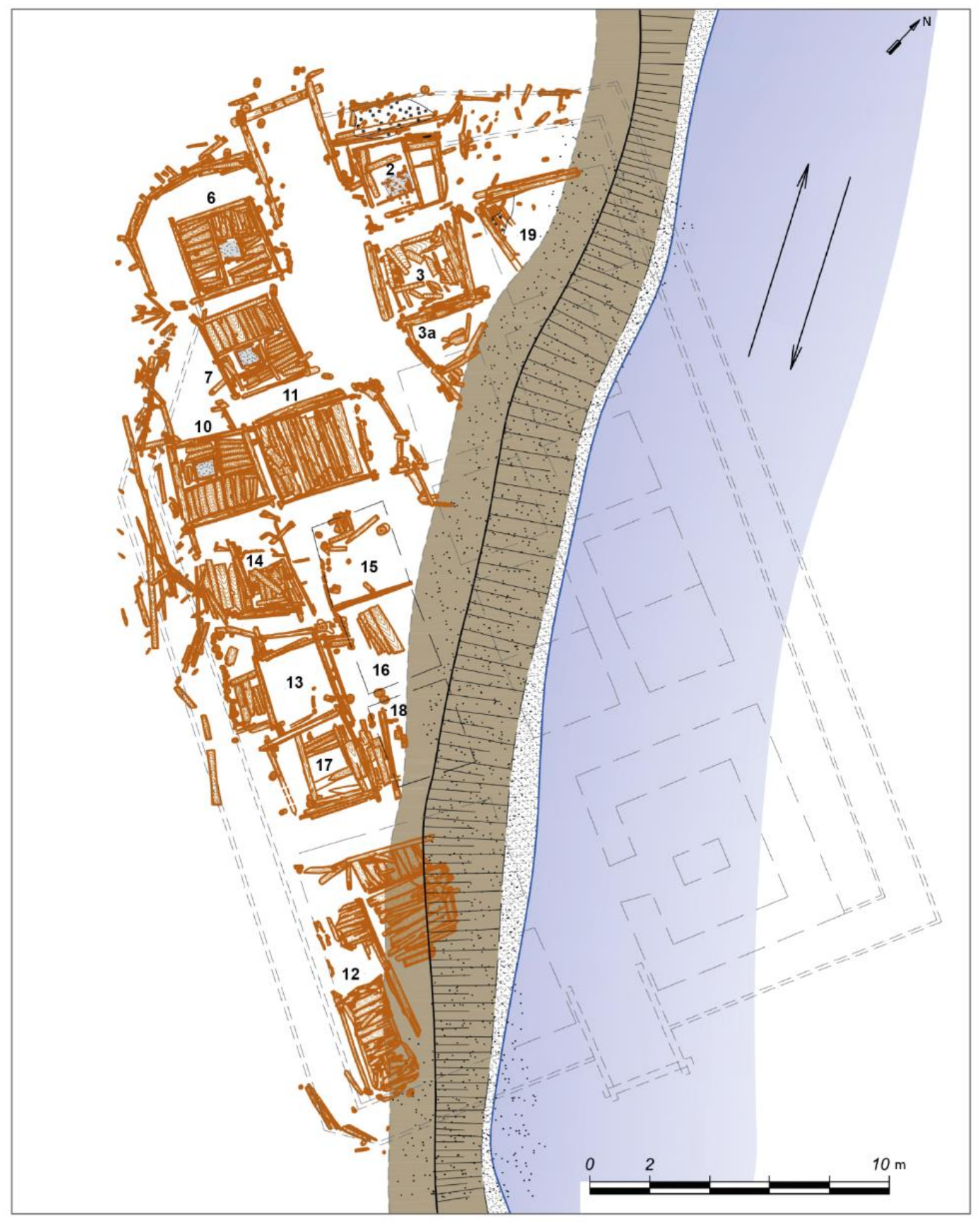


Fig. 7. Reconstruction of the Nadymskyi Gorodok settlement during the 16th century. Each documented and analyzed building is denoted by a number (corresponding to the text).

\subsection{Settlement development}

Korona (2015) mentioned that the inhabitants of the NG settlement used trees and shrubs from immediate surroundings of the settlement as fuel and building material resulting in the extensive disturbance of the woody plants in the local area and the expansion of ruderal vegetation. It is therefore questionable, given the lack of wooden material from nearby local forests, whether the NG settlement was inhabited for 700 years (from the 10th to the 17th century) as proposed by Goryachev et al. (2002) and Shiyatov et al. (2005). Both authors explain the large spread of felling dates within single buildings by a constant re-use of existing timber (Goryachev et al., 2002; Shiyatov et al., 2005). Albeit the critical load-strength effects on the properties of the timber elements are likely negligible due to the simple, one-story construction technique, the moist and warm summer-autumn conditions at the site favor biological degradation of the timber by insects or fungi. Therefore, a constant re-use of the timber is implausible. The occupation of the settlement is still unknown and can be erroneously longer when driftwood as main source of construction material is not considered. Results by Omurova et al. (2013) and the here identified periods of construction activity on the so far excavated cultural layers indicate that the building activity and thus, the function of the settlement was most likely limited to a certain period from the mid-15th to the 16th century only. The absence of older and younger timber cannot be explained by decay or re-use alone since the permafrost ensures perfect preservation conditions of the wood. In a most recent investigation by Kardash et al. (2018) of wooden material from older cultural layers including constructions, building activity in the NG settlement might have started in the mid-14th century.

The considerable variations of the felling dates of the samples even within the same building and the high diversity in timber types and tree species is a characteristic feature of the NG settlement (supplementary Table S1). Such a phenomenon was not observed earlier at northwestern Siberian architectural and archaeological sites (Zharnikov et al., 2014a, 2014b) and thus, confirming our assumption concerning the random origin of the wood.

In comparison, other settlements and monuments that were recently investigated, showed felling dates that lie within short timeframes, for example the Yarte VI settlement, dated to 
1066-1106 AD (Shiyatov and Hantemirov, 2000), the Buchta Nakhodka settlement dated to the second quarter of the 13th century (Sidorova et al., 2017), the settlement Zelenaya Gorka dated to the end of the 13th century and the cemetery in Zelenyi Yar which is dated to $1280 \mathrm{AD}$ (Shiyatov et al., 2005; Slepchenko et.al., 2019) (Fig. 1). In all those examples, the forests were purposely harvested and the trees were used for the constructions. However, there are also cases where dendrochronological dating indicates a long settlement history such as the Ust-Voikar settlement, located ca. $350 \mathrm{~km}$ east of Nadym (Fig. 1), where timber is dated from the end of 13th to the second half of the 17th century, indicating tree felling's during summer (Gurskaya, 2008).

In other cases, felling dates for timber pre-dated written historical sources, for example for the Vtoryye Kresty settlement, Taimyr Peninsula (Myglan and Vaganov, 2005). The utilization of driftwood as a resource for the construction of buildings might be a possible reason for this offset. The NG settlement, however, remains one of the clearest examples of a large distribution of dendrochronological dates (Goryachev et al., 2002; Kardash, 2009; Omurova et al., 2013).

From the general distribution of the samples (Fig. 6), a sharp increase in the number of samples with preserved outermost ring with bark (the 1st group) was observed that falls within the period of 1463 and 1485 AD. Samples with less than 10 missing sapwood rings (our second group) show peaks in felling dates at 1463-1466, 1468, 1470, 1474-1475 and 1482-1484 AD (Fig. 6b). The dates marked for the 2nd group are in agreement and within the periods obtained for the first group of samples (1468 and 1470 fall in the period 1474-1475 and 1482-1484 - in the period of 1484-1485 AD, respectively).

Analysis of the overall distribution of the first and second group of samples (Fig. 6c) showed that the years 1531 and 1537 AD stand out, reflecting felling years mainly from timber used for the palisade, including the north-west entrance (Table 1). An increasing number of samples, which was observed in some years (1460-1465 and 1475-1485 AD), is probably not accidental and can be correlated with periods of high construction activity of the NG settlement. Most likely, those years reflect a high timber demand which lead to logging in remote forest areas.

\subsection{Limitation of dendro-provenance}


This is one of the first studies that takes the usage of driftwood into consideration as a main building material in the NG settlement. Generally, the question of the origin of the timber in western Siberia is not addressed in dendroarchaeological research thus far, making this work highly significant for further studies. The provenance and the usage of driftwood for historical constructions were analysed by Alix (2005) for the Arctic, thereby identifying a climatically- and ecologically-induced driftwood cycle in coastal areas of north-western Alaska. Dickson (1992) analysed driftwood of various tree species from archaeological sites of the western and northern islands of Scotland from the Neolithic era to the 16th century AD, and also states that driftwood was often used as fuel and sometimes for construction purposes. Dyke and Savelle (2000) and also Alix (2005) identified Siberia as one of the source region of larch driftwood, allowing for the dating of their archaeological objects. Hellmann et al. (2015) cross-dated Pinus sylvestris driftwood samples from Greenland, Iceland, Svalbard, and the Faroe Islands with chronologies from the central Siberian Yenisei and Angara Rivers.

Our study demonstrates that driftwood was the main source of building material in the light of an absence of trees in close vicinity of the NG settlement. However, owing to the lack of reference chronologies along the Nadym River and its tributaries, the exact location of the trees' origins remains unknown for now. Additionally, we did not consider the option of a possible delivery of wood for the construction of the buildings in winter by cargo-carrying reindeer sleds. This assumption, however, is negligible because the typical sleds used during the settlement in NG and overall in the traditional indigenous culture of the north were likely dog sleds (Vizgalov et al., 2013).

\section{Conclusion}

The analysis of 271 dated samples from the NG settlement allowed us to determine the time of eleven buildings and parts of the palisade. We demonstrated that only for two buildings were trees from upstream forests felled and utilized. In all other cases, driftwood served as the main building material, dating from the second half of the 15th until the first half of the 16th century. Moreover, we were able to identify four periods of construction activity. The evidenced construction activities began around 1466 AD. After this, repair or rebuilding took place around $1475 \mathrm{AD}$, at the beginning of the 16th century, and after $1530 \mathrm{AD}$. Thus, the documented times for the NG settlement cover the time span from approximately 1460 to the mid-16th century AD. 
23

24

\section{5}

Analysis of the species composition of the samples showed that larch, spruce and pine was widely used in relatively equal proportions. Logs, half-logs and thick planks were mainly used as the building material for log cabins and thinly chopped planks and ship component parts were used for flooring.

We were able, for the first time, to identify the use of driftwood as the main building material based on: the location of the study site in the treeless zone on the bank of the large river, the high variety of the utilized tree species and tree ages, and the considerable spread in the felling dates in samples from the same building. By specifically focusing on the differentiation of logged and drifted material of a large number of samples, a more accurate picture of the existence of the settlement, its history including periods of construction activity and the timber use in NG was possible. We strongly recommend a substantial revision of the previously published dating results for the NG settlement. Our newly developed composite chronology covering more than 600 years is a valuable basis for the dating of other archaeological and historical monuments in the Siberian forest-tundra zone and for future socio-environmental studies.

\section{Acknowledgements}

The authors thank the staff of the non-governmental organization "Severnaya archeologia -1 ” for helping in organizing the archaeological excavations. We express our gratitude to Maria Usolkina, Evguene Trofimov, Aleksei Solovyev and Mikhail Chubinkiy for help during the excavations and preparation of the samples. Special thanks goes to Sascha Börger and Bernhard Muigg for their helpful comments on an earlier draft of this paper and to Justin Davies for assistance with the English editing. This study was supported by Russian Science Foundation (No. 19-14-00028), Krasnoyarsk, Russian Federation. Andrea Seim was financially supported by the German Research Foundation (SE 2802/1-1). 
628

629

630 


\section{References}

Aleksashenko, N.A., Kosintsev, P.A., 2010. Хозяйство населения севера Западно-Сибирский в эпоху железа [The economy of the population of the North West Siberian in the Iron Age]: (in russian), in: Alekseev, V.V. (Ed.), История Ямала [History of the Yamal], vol. 1, Basko, Yekaterinburg, pp. 156-182.

Alix, C., 2005. Deciphering the impact of change on the driftwood cycle: contribution to the study of human use of wood in the Arctic. Global and Planetary Change 47 (2-4), 83-98.

Alix, C., and Brewster, K., 2004. Not all driftwood is created equal: wood use and value along the Yukon and Kuskowim Rivers, Alaska. Alaska journal of anthropology, 2(1), 2-19.

Bartholin, T., 1979. The Picea-Larix problem. IAWA bulletin - International Association of Wood Anatomists. New Series, 7-9.

Benkova, V.R., Schweingruber, F.H., 2004. An anatomy of Russian woods: an atlas for the identification of trees, shrubs, dwarf shrubs and woody lianas from Russia: [Анатомия древесины растений России: Атлас для идентификации древесины деревьев, кустарников, полукустарников и древесных лиан России], 1. Aufl. ed. Haupt, Bern, 456pp.

Briffa, K.R., Melvin, T.M., Osborn, T.J., Hantemirov, R.M., Kirdyanov, A.V., Mazepa, V.S., Shiyatov, S.G., Esper, J., 2013. Reassessing the evidence for tree-growth and inferred temperature change during the Common Era in Yamalia, northwest Siberia. Quaternary Science Reviews 72, 83-107.

Chernych, N.B., 1996. Дендрохронология и археология [Dendrochronology and archaeology]. (in russian). Nox, Moskva, 212pp.

Chudinov, B.S., Tjurikov, F.T., Zuban, P.E., 1965. Древесина Лиственницы И Ее Обработка [Larch Wood And Its Processing]. (in russian). Лесная промишленность [Forest Industry].

Cook, E.R., Krusic, P.J., 2008. ARSTAN - A Tree-Ring Standardization Program Based on Detrending and Autoregressive Time Series Modeling. Tree-Ring Lab (TRL) - Lamont Doherty Earth Observatory.

Dickson, J.H., 1992. North American driftwood, especially Picea (spruce), from archaeological sites in the Hebrides and Northern Isles of Scotland. Review of Palaeobotany and Palynology 73 (1-4), 49-56.

Douglass, A.E., 1919. Climatic Cycles and Tree-growth Bd. 1. Carnegie Institution of Washington.

Dyke, A.S., Savelle, J.M., 2000. Holocene Driftwood Incursion to Southwestern Victoria Island, Canadian Arctic Archipelago, and Its Significance to Paleoceanography and Archaeology. Quat. res. 54 (01), 113-120.

Eckstein, D., 2007. Human time in tree rings. Dendrochronologia 24 (2-3), 53-60.

Forsyth, J., 1994. A history of the peoples of Siberia: Russia's North Asian colony 1581-1990. Cambridge University Press.

Goryachev, V.M., Goryacheva, T.A., Kardash, O.V., 2002. Хронология «Надымского городища» (Ямало-Ненецкий автономный округ) с помощью древесно-кольцевого 
анализа. Хронология и стратиграфия археологических памятников голоцена Западной Сибири и сопредельных территорий: Материалы науч. семинара (Тюмень, 18-19 нояб. 2001 г.): [Chronology of the "Nadym settlement" (Yamal-Nenets Autonomous District) by tree-ring analysis. Chronology and Stratigraphy of Archaeological Monuments of the Holocene of Western Siberia and Adjacent Territories: Materials of the Scientific Seminar (Tumen, 18-19 November 2001)]. (in russian), Tumen, 22-24.

Grabner, M., Klein, A., Geihofer, D., Reschreiter, H., Barth, F.E., Sormaz, T., Wimmer, R., 2007. Bronze age dating of timber from the salt-mine at Hallstatt, Austria. Dendrochronologia 24 (2-3), 61-68.

Griebel, B., 2013. Building from the ground up: Reconstructing visions of community in Cambridge Bay, Nunavut. Études/Inuit/Studies, 37(1), 9-33.

Gurskaya, M.A., 2008. Дендрохронологическая датировка археологических образцов древесины городища Усть-Войкарского (Северо-Западная Сибирь): [Dendrochronological dating of archaeological wood of Ust Voikar settlement (NorthWestern Siberia)], in: Kosintsev, P.A. (Ed.), Фауны И Флоры Северной Евразии В Позднем Кайнозое [Fauna And Flora Of Northern Eurasia In The Late Cenozoic]. Russian Acad. Sciences. (in russian), vol. 6. Rifey, Екатеринбург [Ekaterinburg], pp. 212-231.

Hantemirov, R.M., 2009. Динамика Древесной Растительности И Изменения Климата На Севере Западной Сибири В Голоцене [Dynamics of Tree Vegetation and Climate Change in the North of Western Siberia in the Holocene]: (in russian). Dissertation, Екатеринбург [Ekaterinburg].

Hantemirov, R.M., Shiyatov, S.G., 2002. A continuous multimillennial ring-width chronology in Yamal, northwestern Siberia. The Holocene 12 (6), 717-726.

Hellmann, L., Tegel, W., Kirdyanov, A.V., Eggertsson, Ó., Esper, J., Agafonov, L.I., Nikolaev, A.N., Knorre, A.A., Myglan, V.S., Olga Churakova, Schweingruber, F.H., Nievergelt, D., Verstege, A., Büntgen, U., 2015. Timber Logging in Central Siberia is the Main Source for Recent Arctic Driftwood. Arctic, Antarctic, and Alpine Research 47 (3), 449-460.

Hellmann, L., Agafonov, L., Churakova, O., Düthorn, E., Eggertsson, Ó., Esper, J., Nikolaev, A. N. Kirdyanov, A.V., Knorre, A.A., Moiseev, P., Myglan, V.S., Reinig, F., Schweingruber, F., Solomina, O., Tegel, W., Büntgen, U., 2016. Regional coherency of boreal forest growth defines Arctic driftwood provenancing. Dendrochronologia, 39, 3-9.

Hollstein, E., 1980. Mitteleuropäische Eichenchronologie: Trierer dendrochronologische Forschungen zur Archäologie und Kunstgeschichte. Trierer Grabungen und Forschungen 11. von Zabern, Mainz am Rhein, 273 pp.

Holmes, R.L., 1994. Dendrochronology Program Library (DPL). University of Arizona. http://www.ltrr.arizona.edu/pub/dpl-mac/68k/dpl.txt. Accessed 13 February 2018.

Kardash, O.V., 2009. Надымский городок в конце XVI - первой трети XVIII вв. История и материальная культура [Nadymsky Gorodok at the end of XVI-first third of the XVIII century. History and material culture]. (in russian). Magellan, Ekaterinburg, Surgut, 360 pp. 
Kardash, O.V., 2013. Nadymsky Gorodok knyazey Bolchoy Karachey [Nadymsky Gorodok under Princes of Bolchaya Karacheya]. (in russian). Magellan, Yekaterinburg-Salekhard.

Kardash, O.V., Lips, S.A., Sidorova, M.O., Myglan, V.S., Lobanova, T.V., 2018. Надымский городок: новые данные о хронологии в русском освоении Севера Западной Сибири в XIII-XIV веках [Nadym settlement: new data on chronology in Russian development of the North of Western Siberia in XIII-XIV centuries]: (in russian), in: Lapshin, V.A. (Ed.), Археология Севера России: Югра - волость Новгорода Великого в XI-XV вв. Свод источников и исследований [Archeology of the North of Russia: Ugra - Novgorod the Great Volost in the $11^{\text {th }}-15^{\text {th }}$ centuries. Compilation of sources and studies]. (in russian), 1 ed. Институт археологии Севера [Institute of Archeology of the North], pp. 346-381.

Kharuk, V.I., Im, S.T., Naurzbaev, M.M., Ranson, K.J., 2004. Temporal dynamics of larch in the forest-tundra ecotone. Doklady Earth Sciences. T. 398. № 7. pp. 1020-1023.

Korona, O., 2015. Archaeobotanical finds from the Nadymsky Gorodok medieval settlement in the forest-tundra of Western Siberia, Russia. Veget Hist Archaeobot 24 (1), 187-196.

Kosintsev, P.A., 2005. Ecologiya srednevekovogo naseleniya severa Zapadnoii Sibiri. Istoshniki [Ecology medieval population north of Western Siberia. Sources]. (in russian). Ural University Press, Yekaterinburg-Salechard.

Kristjansdóttir, S, Lazzeri, S, Macchioni, N., 2001. An Icelandic medieval stave church made of drift timber: the implications of the wood identification. Journal of Cultural Heritage; 2 (2): 97-107.

Myglan, V.S., Vaganov, E.A., 2005. Вопросу О Датировке Исторических Памятников На Таймырском Полуострове: Дендрохронологический И Исторический Аспекты [About Dating Historical Monuments on the Taimyr Peninsula: Dendrochronological and Historical Aspects]. in russian. Вестник Красноярского Государственного Университета [Bulletin of Krasnoyarsk State University] 5, 176-182.

National Oceanic and Atmospheric Administration (NOAA), 2017. Paleo Data Search: International Tree-Ring Databank (ITRDB). https://www.ncdc.noaa.gov/paleosearch/?dataTypeId=18. Accessed 31 December 2017.

Nicolussi, K., Kaufmann, M., Melvin, T.M., van der Plicht, J., Schießling, P., Thurner, A., 2009. A 9111 year long conifer tree-ring chronology for the European Alps: a base for environmental and climatic investigations. The Holocene 19 (6), 909-920.

Omurova, G.T., Barinov, V.V., Kardash, O.V., Myglan, V.S., 2013. Установление времени строительства (перестройки) Надымского городка: дендрохронологический аспект [Periods of Construction (Reconstruction) of Nadymsky Gorodok: Dendrochronological Aspect]. (in russian). Journal of Siberian Federal University. Biology 2, 185-195.

Omurova, G.T., Barinov, V.V., Kardash, O.V., Vaganov, E.A., Myglan, V.S., 2018. Reconstruction Of Extreme Paleoclimatic Events In Northwestern Siberia Using Ancient Wood From Fort Nadym. Archaeology, Ethnology and Anthropology of Eurasia 46 (3), $32-$ 40. 
Plujnikov, V.I., 1995. Термины российского архитектурного наследия [Terms of Russian architectural heritage], Москва [Moscow].

Rinn, F., 1996. TSAP, v3.5 - Computer Program for Tree-ring Analysis and Presentation. Frank Rinn Distribution, Heidelberg.

Schweingruber, F.H., 1990. Microscopic wood anatomy: Structural variability of stems and twigs in recent and Subfossil Woods from Central Europe, $3^{\text {rd }}$ ed. ed. Swiss Federal Institute for Forest, Snow and Landscape Research, Birmensdorf, $226 \mathrm{pp}$.

Shiyatov, S.G., 1980. Датировка деревянных сооружений Мангазеи дендрохронологическим методом [Dating of wooden constructions of Mangazeya by dendrochronological method]. (in russian), in: Belov, M.I., Ovsyannikov, O.V., Starkov, V.F. (Eds.), Мангазея. Мангазейский морской ход. Часть 1 [Mangazeya. Mangazean Sea Route. Part 1]. (in russian). Гидрометеоиздат [Gidrometeoizdat], Leningrad, pp. 93-107.

Shiyatov, S.G., Hantemirov, R.M., 2000. Дендрохронологическая датировка древесины кустарников из археологического поселения Ярте-6 на полуострове Ямал [Dendrochronological dating of shrubs from the archeological settlement of Yarte- 6 on the Yamal Peninsula], in: Golovnev, A.V., Shorin, A.F., Chemyakin, Y.P. (Eds.), Древности Ямала [Antiquities of Yamal]. (in russian), vol. 1. Институт истории и археологии УРО PAH [Institute of History and Archaeology of the Ural Branch of the Russian Academy of Sciences], Ekaterinburg, pp. 112-120.

Shiyatov, S.G., Hantemirov, R.M., Goryachev, V.M., Agafonov, L.I., Gurskaya, M.A., 2005. Дендрохронологические Датировки Археологических Исторических И Этнографических Памятн Западной Сибири [Dendrochronological dating of archaeological, historical and ethnographic sites in West Siberia], in: Chernych, N.B., Zavyalov, V.I. (Eds.), Археология и естественнонаучные методы. Сб. статей [Archaeology and natural sciences. Collection of articles]. (in russian), pp. 43-57.

Sidorova, M.O., Büntgen, U., Omurova, G.T., Kardash, O.V., Myglan, V.S., 2017. First dendroarchaeological evidence of a completely excavated medieval settlement in the extreme north of Western Siberia. Dendrochronologia 44, 146-152.

Slepchenko, S. M., Gusev, A. V., Svyatova, E. O., Hong, J. H., Oh, C. S., Lim, D. S., \& Shin, D. H. (2019). Medieval mummies of Zeleny Yar burial ground in the Arctic Zone of Western Siberia. PloS one, 14(1), e0210718. doi:10.1371/journal.pone.0210718.

Vaganov, E.A., Shiyatov, S.G., 2005. Dendroclimatic and dendroecological studies in Northern Eurasia // Forestry. No. 4. 18-27.

van de Gevel, S.L., Hart, J.L., Grissino-Mayer, H.D., Robinson, K.W., 2009. Tree-Ring Dating Of Old-Growth Longleaf Pine (Pinus palustris Mill.) Logs From An Exposed Timber Crib Dam, Hope Mills, North Carolina, U.S.A. Tree-Ring Research 65 (1), 69-80.

Vizgalov, G.P., Kardash, O.V., Kosintsev, P.A., Lobanova, T.V., 2013. Историческая экология населения севера Западной Сибири [Historical ecology of the population of the north of Western Siberia]. (in russian). Institut Archeologii Severa, Neftejugansk, Ekaterinburg, pp. 374 . 
789 Zharnikov, Z.Y., Rudkovskaya, M.A., Vizgalov, G.P., Myglan, V.S., 2014a. 790 Dendrochronological Dating of Buildings in the Central Part of the Residential Area at the 791 Staroturukhansk Fortified Settlement1. Archaeology, Ethnology and Anthropology of Eurasia $792 \quad 42(2), 67-76$.

793 Zharnikov, Z.Y., Rudkovskaya, M.A., Vizgalov, G.P., Myglan, V.S., 2014b. Результаты 794 дендрохронологической датировки Стадухинского острога [The results of the tree-ring 795 dating of the Stadukhino prison]. Российская археология [Russian Archaeology] 2, 164$796 \quad 170$.

797 